\title{
Protein ALEX
}

National Cancer Institute

\section{Source}

National Cancer Institute. Protein ALEX. NCI Thesaurus. Code C126521.

Protein ALEX (626 aa, $\sim 68 \mathrm{kDa}$ ) is encoded by the human GNAS gene. This protein plays a role in the inhibition of adenylate cyclase-stimulating $\mathrm{G}$ alpha proteins. 